\title{
Applications of single-tree selection guideline following a DBq approach on Nepal's community forests
}

\author{
E. Cedamon ${ }^{1 *}$, G. Paudel ${ }^{2}$, M. Basyal ${ }^{2}$, I. Nuberg ${ }^{1}$ and K. K. Shrestha ${ }^{3}$
}

\begin{abstract}
There is growing interest by forest users, government forest officers and policy makers on maximising forest goods and livelihood provisions from community forestry in a sustainable manner. However, the way several mature community forests are currently managed based on selection, e.g. negative thinning and crown thinning, is questionable as it results to decline in forest stock, timber quality and regeneration. To assist forest users in managing their community forests, an action research was implemented in Kavre and Lamjung to manage planted Pine (Pinus spp.) and naturallyregenerated Sal (Shorea robusta) through selection system. This paper describes the q-factor and its relevance for sustainable community forest management in Nepal. The simple guideline for selection system introduced to 30 community forest users groups in six sites are presented for wider adoption and policy recommendation.
\end{abstract}

Key words: Forest goods and services, livelihoods, regeneration, stand structure, sustainable forest management

$\mathrm{T}^{\mathrm{s}}$ he ongoing campaign for scientific forest management (SFM) in Nepal is now challenging the community forestry sector to implement silviculture systems in the management of community forests. There are few examples of silviculture systems at work on community forests that are efficient both at increasing timber production and rate of regeneration. This paper describes a selection silviculture system guided by q-factor, diameter class limit and target basal area as a promising management system for a considerable areas of community forests.

Community forests in Nepal to date have an area of about 1.8 million hectares managed by 18,960 community forest users groups (DoF, 2015). The area of community forests represents about a third of the countries forest cover of 5.96 million hectares and a national average growing stock is $165 \mathrm{~m}^{3} /$ ha where High Mountains and High Himal physiographic regions together has the highest growing stock of $225 \mathrm{~m}^{3} / \mathrm{ha}$ whereas Middle Mountains has the lowest growing stock of 124 $\mathrm{m}^{3} /$ ha (DFRS, 2015). The average tree density is 430 stems per hectare where $67 \%$ of these stems are small poles $(10-20 \mathrm{~cm}$ diameter at breast height, DBH), $18 \%$ are large poles $(20-30 \mathrm{~cm}$ $\mathrm{DBH})$, and $15 \%$ saw $\log /$ timber $(>30 \mathrm{~cm} \mathrm{DBH})$.
The diameter class distribution from this national forestry outlook suggests that a management system is needed to be in place so that growth and vigour of small poles are promoted when saw logs are harvested. A selection silviculture system is generally applicable for such forest structure and management objectives.

Community forests are the main source to fulfil subsistence needs of timber, firewood, fodder and leaf litter for majority of the rural population in Nepal. Community forest management is undergoing a level of redefinition particularly with regards to efficiently increasing production of forest products to improve forest-based livelihood and efficiently regenerating healthy forests. Cedamon et al. (2016) in their rapid silviculture appraisal found that selection and shelter wood systems are preferred by community forest users. These silviculture systems appeal to forest users because of the potentials of planting fodder trees and grasses, non-timber forest products (NTFPs), and medicinal and aromatic plants (MAPs) on the forests after applying treatments. Scientific forest management is now a concept being promoted by the Department of Forests (DoF) for sustainable management and use of forests. However, silviculture practices in

\footnotetext{
School of Agriculture, Food and Wine, The University of Adelaide, Waite Campus, Urrbrae, South Australia.

*E-mail: edwin.cedamon@adelaide.edu.au

${ }^{2}$ Forest Action Nepal, Bagdole, Lalitpur, Nepal

${ }^{3}$ School of Social Science, University of New South Wales, Sydney, New South Wales, Australia 
community forests are yet at early stages of trials and some silviculture practices are confusing to forest users.

The Scientific Forest Management Guideline 2015 (DoF, 2015) suggests clear felling, selection and shelter wood silviculture systems that may be applied on a community forest but the guideline is only about shelterwood system. In support of the Government of Nepal's campaign on 'forestry for prosperity' through the scientific forest management, the Australian Centre for International Agriculture Research (ACIAR) EnLiFT Project ${ }^{4}$ initiated a participatory action research (PAR) to investigate forest and people's responses to different silviculture systems. This paper describes why selection system is a promising management system for many community forests and how this can be implemented. A simple implementation guideline is provided as used in the EnLiFT silviculture Pine forest and Sal forest demonstration works in Kavrepalanchowk and Lamjung districts, respectively.

\section{Taxonomic description and distribution}

The decision to practice any silvicultural system is primarily based on combination of factors including silvicultural characteristics of species, current forest stand structure and diameter distribution and forest management objectives. For implementation of selection silviculture system the following three components have to be taken into consideration: residual stocking, diameter class limit and target diameter distribution. But what is selection silviculture? Smith et al. (1997) define selection silviculture as silviculture programmes that are used to manage multi-age stand where a system of tree selection for residual trees is employed for harvesting, establishing and developing regeneration. Smith et al. (1997) and Helms (1998) described that in selection system, mature tree is harvested either as single scattered trees or in small groups at short interval to open growing space for regeneration and these cuttings are repeated indefinitely.

Implementing selection system requires an understanding of the current forest structure and a target future structure that will support the needs of forest users. Generally Nepal's forests are composed of natural forest and plantations. Natural forests have multi-age ${ }^{5}$ classes, although some may have attained even-age stand structure. But many plantations too, which are expected to have even-aged stand structure, have developed into multi-age classes or at least three crown classes. Based on the report of Department of Forest research and Survey (DFRS, 2015), the forest structure in Nepal can be described based on the diameter distribution. DFRS (2015) estimated seedlings $(<1.3 \mathrm{~m}$ height $)$ of $10,095 /$ ha, small saplings ( $\geq 1.3 \mathrm{~m}$ height, $<5 \mathrm{~cm} \mathrm{DBH}$ ) of 1045/ha, large saplings (5-10 cm DBH) of $426 / \mathrm{ha}$, small poles $(10-20 \mathrm{~cm} \mathrm{DBH})$ of $287 /$ ha, large poles $(20-30 \mathrm{~cm} \mathrm{DBBH}) 79 / \mathrm{ha}$, small saw $\log (30-50 \mathrm{~cm} \mathrm{DBH})$ of 46 stems $/$ ha and large saw $\log (\geq 50 \mathrm{~cm} \mathrm{DBH})$ of 18 stems/ha. This forest structure is confirmed by few case studies including Cedamon et al. (2016) and Awasthi et al. (2015). The current stand structure of community forests in Nepal has been achieved through harvesting based on ad hoc selection and sometimes high grading creating openings on the stand allowing natural regeneration to occur.

Community forest in Nepal has been a major for timber, firewood, fodder and leaf litter for millions of rural people. While these forest products are derived by forest users for their subsistent needs, many community forest groups aspire to utilise timber for commercial purposes to drive economic development of the group but retaining a significant forest cover on the stand. The current silviculture practice however is not effective in supplying timber in large-quantity for driving forest based enterprises and inefficient in developing healthy regeneration. Silviculture practice on community forests therefore has to change if forests users have to increase timber supply and managed stand openings for better and healthy regeneration.

Selection system is an alternative silviculture system for community forests in Nepal that has great potential for increasing supply of timber from current stand at the same time maintaining forest cover and promoting healthy regeneration on newly opened spaces. Larsen (1995) argued that selection system maintains a stable complex forest structure through efficient biogeochemical cycle determined through release of open spaces for regeneration. Managing and maintaining

\footnotetext{
${ }^{4}$ EnLiFT Project is an action research project funded by Australian Centre for International Agricultural Research (ACIAR).

The aim of the project is to enhance food security and livelihood through improved agroforestry and community forestry in Nepal.

${ }^{5}$ The term multi-age is adopted instead of the term uneven age following O'Hara (2014) to include two-age stands which are common in some community forests in Nepal.
} 
multi-age stand is now a priority worldwide due to complex societal needs and due to inherently long-term nature of forest management, forest should be managed to be able to resist local disturbances and global environmental and climate changes (O'Hara, 2014). Selection system is generally classified into two broad groups single tree selection and group selection. While group or strip selection may be suitable for some community forests, single tree selection has been implemented in many community forests though ad hoc basis. Therefore, aim of this paper is to provide a more scientific and technical guidance into the single tree selection silviculture system to increase timber supply and achieve efficient regeneration establishment and improve health and quality of residual and new trees.

\section{DBq approach for single tree selection system on Nepal's community forest}

As means of organising stand treatments or operations for tending, harvesting and reestablishing new forests (regeneration), silviculture systems provide means for maintaining or achieving a desired stand structure and that for multi-aged stand selection silviculture is widely applied. A number of approaches for managing or achieving a multi-age stand but the widely used are $\mathrm{DBq}$ approach, plenter system, allocation by stand density index, and leaf area allocation (O'Hara and Gersonde, 2004). Stand density index and leaf area allocation are technically complicated perhaps beyond forest capability. The plenter system on the other hand is also technically complicated because of the requirement to at least know the standing timber volume (which should be maintained over long-term period) and growth rates so that harvest volume is equal to growth (equilibrium). The DBq approach which builds upon decisions on upper diameter class for which a number of trees has to be retained (D), a desired basal area (B) and a Q-factor (q). q- factor which ranges from 1.2 to 2.0 , represents the frequency of the trees resembling and inverse $\mathrm{J}$ curve or an inverse exponential function. A q-factor of 2 means a particular diameter class is twice as many as the next larger diameter class while a q-factor of 1 represents equal distribution of trees across diameter classes or represented by a flat line. Smith et al. (1997) described that a stable equilibrium can be achieved by $\mathrm{DBq}$ approach by maintaining a diameter distribution defined by $\mathrm{DBq}$ after harvest or mortality. DBq approach has been proven by the EnLiFT Project to be easily understood and implemented by forest users in Nepal because diameter distribution and target diameter limits are readily available information. A routine of calculations is necessary to obtain the residual stocking for DBq. The first step in this calculation is determination of target basal area and maximum diameter at breast height for residual trees. A target basal area of $30 \mathrm{~m}^{2}$ has been widely used in selection system and is adopted by the EnLiFT Project as suitable for community forests in Nepal. It is to be noted however that many community forests have basal areas $<30$ $\mathrm{m}^{2}$ (Cedamon et al., 2016), the aim therefore for selection system is basal area increase from high quality trees. The rapid silviculture appraisal conducted by Cedamon et al. (2016) revealed that the diameter limits for residual trees on community forests ranges from 40 to $50 \mathrm{~cm}$ (though a few trees larger than $50 \mathrm{~cm}$ may present and protected as mother trees). Once an appropriate diameter limit and basal area for the community forest are determined, the next step is to choose a $\mathrm{K}$ value from table 1 for q-factors 1.1-1.6 and range of diameter class limit calculated by Cancino and Gadow (2002). The residual stocking for the largest diameter class is obtained by dividing the target basal area by the $\mathrm{K}$ value corresponding for the desired q-factor and maximum diameter, e.g. the residual stocking for $35-40 \mathrm{~cm}$ DBH class for q-factor of 1.2 is 53 trees per ha (tph) (30/0.567). The residual stocking for the next lower DBH class is obtained by multiplying the stocking of the next larger diameter class with the desired q-factor, e.g. the stocking for $30-35 \mathrm{~cm} \mathrm{DBH}$ class is $63(52.91 \times 1.2)$.

Table 1: $\mathrm{K}$ values for range of $\mathrm{q}$-factors and diameter limits based on Cancino and Gadow (2002)

\begin{tabular}{cccccccc}
\hline $\begin{array}{l}\text { Maximum } \\
\text { DBH (cm) }\end{array}$ & $\begin{array}{c}\text { Number of } \\
\text { classes }\end{array}$ & $\mathbf{1 . 1}$ & $\mathbf{1 . 2}$ & $\mathbf{1 . 3}$ & $\mathbf{1 . 4}$ & $\mathbf{1 . 5}$ & $\mathbf{1 . 6}$ \\
\hline 40 & 8 & 0.475 & 0.567 & 0.684 & 0.829 & 1.011 & 1.237 \\
45 & 9 & 0.681 & 0.840 & 1.048 & 1.320 & 1.675 & 2.139 \\
50 & 10 & 0.945 & 1.204 & 1.558 & 2.044 & 2.709 & 3.618 \\
\hline
\end{tabular}


Following Cancino and Gadow (2002) the $\mathrm{DBq}$ distribution for basal areas of $30 \mathrm{~m}^{2}$ and $40 \mathrm{~m}^{2}$, diameter limits of 40,45 and $50 \mathrm{~cm}$ and for q-factors 1.2 to 1.6 are provided in figure 1 (please see related ideal stocking table in appendix 1), although, the choice of a q-factor depends in species and site (Smith et al., 1997). Figure 1 provides some guidance on choosing a q-factor appropriate for a community forest. It is evident that lower q factors, e.g. 1.2 would result to higher stocking trees in the largest diameter limits similarly but a lower stocking required in the lowest diameter class resulting to a relatively flatter inverse $\mathrm{J}$ curve. Therefore, when forest management is aimed for a more frequent cutting or a shorter cutting cycle a lower q-factor may seem to be an appropriate choice. The decision on maximum diameter limit depends on the current stocking of large trees where more diameter
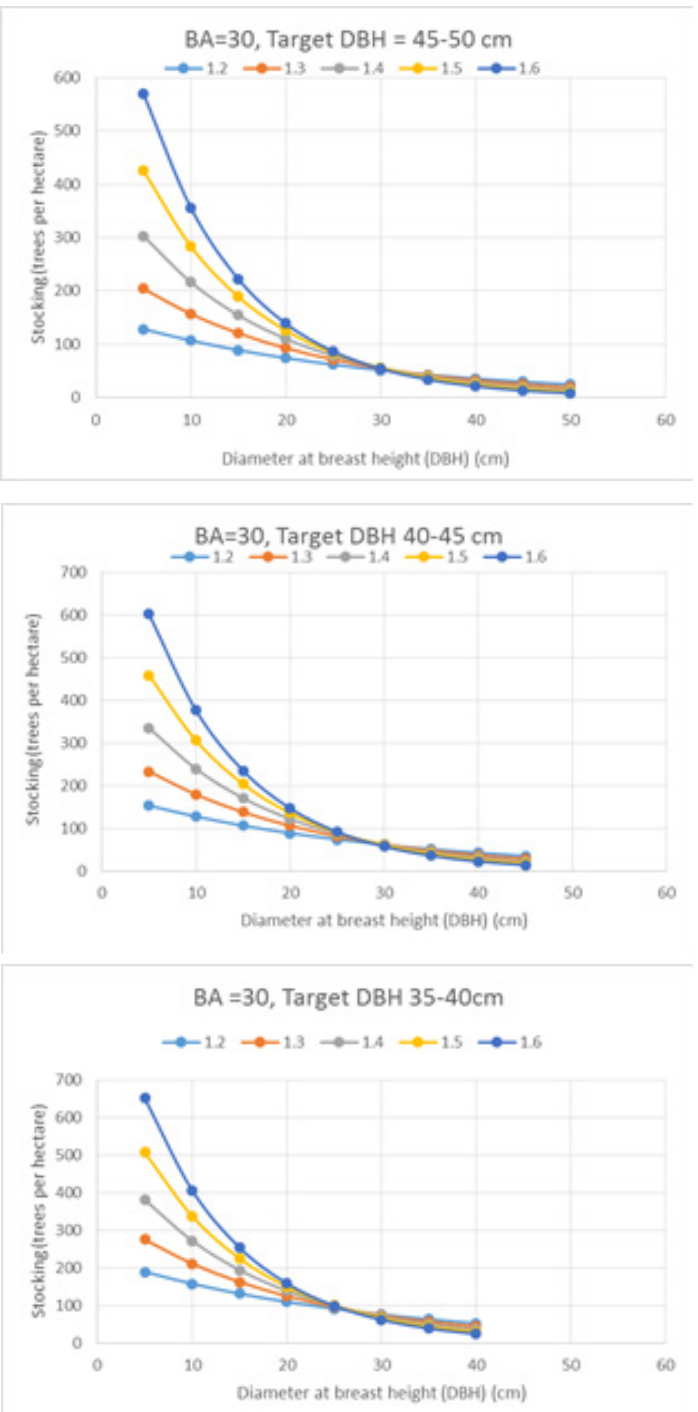

classes will require higher stocking for larger trees, i.e. $<40 \mathrm{~cm} \mathrm{DBH}$. For example, the stocking requirement for residual in $<35 \mathrm{~cm}$ DBH is 91 tph, 79 tph and 53 tph for diameter class limits of $45-50 \mathrm{~cm}, 40-45 \mathrm{~cm}$, and $35-40 \mathrm{~cm}$, respectively. The frequency however of trees above $<40 \mathrm{~cm}$ is generally low for many community forests and therefore having a higher diameter class limit is almost unachievable for these forests. An aim for retaining higher number of larger trees will mean an extremely low harvest of sawlogs. A diameter class limit of 35-40 cm seemed to be a compromise of ensuring timber harvests as well as maintaining forest cover. As expected, the effect of higher basal means a proportionate increase of about $33 \%$ on stocking across diameter classes. While seedlings may be naturally available in some forest types particularly Sal forests, some dense forests like Pine plantation may have low
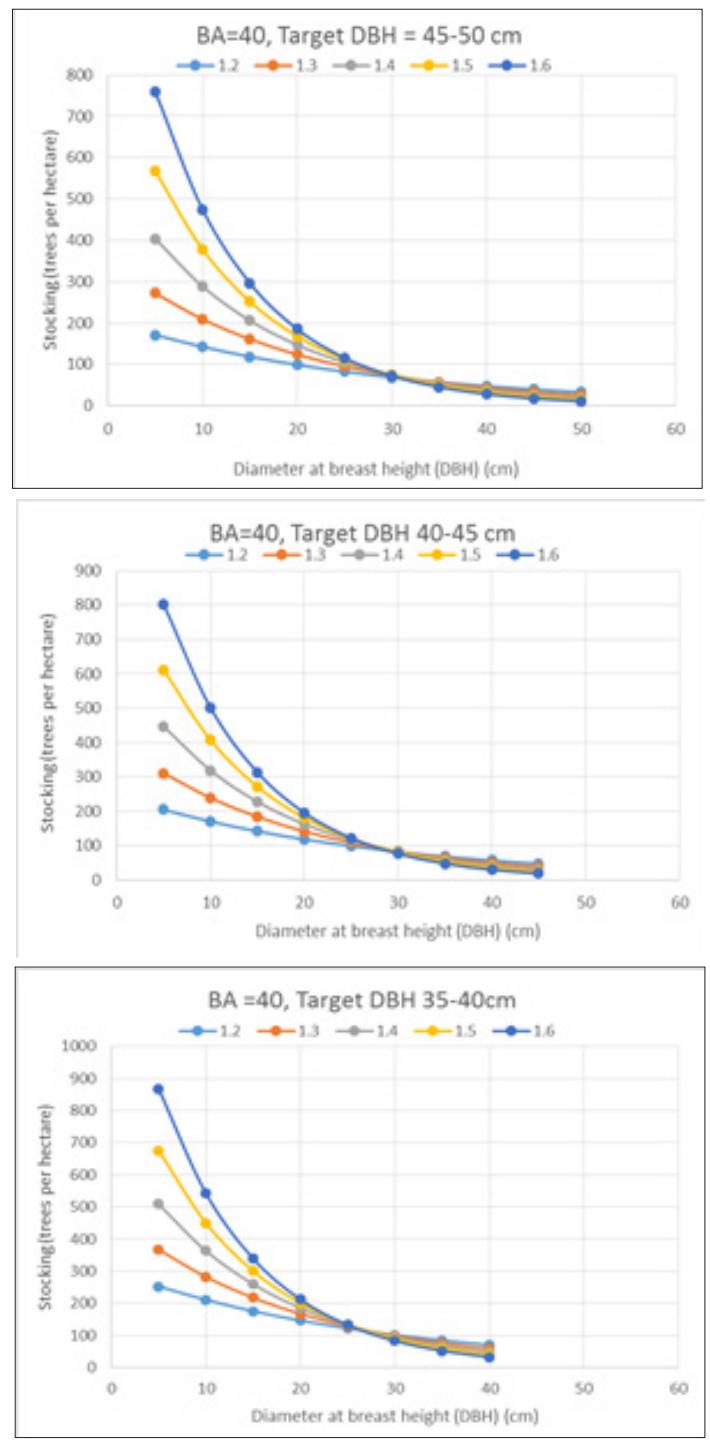

Fig. 1: Ideal stocking distribution of a 1-hectare forest based on $\mathrm{DBq}$ for basal area $30 \mathrm{~m}^{2}$ and $40 \mathrm{~m}^{2}$ for $40-50 \mathrm{~cm}$ DBH limits and q-factors, 1.2 to 1.6 
natural regeneration with exception to those that are affected by frequent fires. For forest with extremely regeneration, the ideal stocking for diameter class $0-5 \mathrm{~cm}$ will serve as a guide for minimum number of seedlings that may be required for planting in areas opened after harvesting.

\section{Selection of silviculture trials in Nepal}

Examples from the EnLiFT Project silviculture demonstration plots are now provided to show how single tree selection silviculture system can be implemented. The first step in the implementation of any silviculture system is to obtain information on the existing stand structure and diameter distribution of the forest to be treated. This required an inventory in the demonstration plots, which was carried out by the members of the forest users groups (FUGs) after a hands-on training provided by the EnLiFT. Then, the FUGs and the executive committee members were consulted in a forest field day to present the inventory and decide for the silviculture treatments to be applied. During the consultation, a proposed silviculture regime was presented using graphs of the current and proposed stand stocking based on $\mathrm{DBq}$ approach. A q-factor of 1.2 and 1.3 was proposed for single tree selection system for timber production and conversion of the current stand into a timber-fodder forest garden.

\section{Example of application of $\mathrm{DBq}$ regime for Chapani Pine forest (Chaubas, Kavre)}

The Chapani community forest covers an area of 83 hectares. Pinus wallichiana (Gobre Salla) and Pinus patula (Patle Salla) were planted in the early 1980s. It is managed by 117 households located in Chaubas, Kavre District (Nepal Australia Community Resource Management and Livelihoods Project, 2006). Chapani forest was established by the Nepal Australian Forestry Project and the initial aim was generally to reforest the denuded hills providing villagers with timber, fuel wood and fodder. The forest provides timber, fuel wood, leaf litter and grasses to meet forest users' needs. Additionally, the CFUG also sells a small amount of timber from the forest to the Chaubas saw mill, of which it is a component of the forest comprising the sawmill board.
A small portion of the forest has been thinned at around 8-10 years old, but after then forestry operation has been dominated mainly with regular (yearly) small volume of harvest of fuel wood and timber, generally guided by an extremely conservative annual allowable cut. Grasses and leaf litter are regularly collected in the forests generally by women but they often compete for good quality grasses due to closed forest canopy. The Chapani CFUG is in consensus that forest management should improve to increase harvest volumes as well as to increase grass growth in open spaces.

From the analysis of forest inventory data of the plots, it is found that the size of trees on the demonstration plot before treatment was found to range from $10 \mathrm{~cm}$ to $55 \mathrm{~cm}$ where the highest stocking was 136 trees per hectare at DBH class 20-25 cm (Fig. 2, supplemented in Table 2) with declining stocking from this DBH class. The low stocking above $40 \mathrm{~cm}$ DBH classes are attributed to negative selection regime where only the dead, dying, diseased and deformed trees were harvested indicating low quality of large trees and generally of the whole forest. It is also notable that poles (10-20 cm DBH class) were approximately $22 \%$ of the total stocking, but the quality of these trees is low with small and dying crown due to lack of growing space. It is believed that most of these poles are of the same age with the large trees but has stagnated due to lack of thinning. The last time the stand was harvested is believed to be 8-12 years before the EnLiFT demonstration plot is established indicating the inability of previous harvests to encourage regeneration establishment.

Following $\mathrm{DBq}$ single tree selection regime, a considerable number of trees from DBH classes $15-40 \mathrm{~cm}$ and removal of all trees over $40 \mathrm{~cm}$ is suggested. Using the marking guide in table 2 used by the CFUG in selecting and marking residual trees, $30 \%$ of the standing tree volume was harvested. Due to the aim of distributing residual trees within the plot and achieving the minimum stocking for $10 \mathrm{~m} \times 20 \mathrm{~m}$ marking plot, some trees from over $40 \mathrm{~cm}$ DBH was retained. Heavy thinning was also done in DBH classes, $15 \mathrm{~cm}-30 \mathrm{~cm}$ to remove dying, diseased, dead and deformed trees. After treatment, Michelia champaca (Champ)) seedlings were planted to achieve a total stocking of around $900 \mathrm{tph}$. A plot 
demonstrating conversion of the Pine plantation to timber forest garden was also established in the Chapani forest guided by ideal DBq stocking q-factor 1.3. A q-factor of 1.3 was chosen for timber fodder forest garden because of the low stocking requirement for large trees and higher stocking in lower diameter classes.

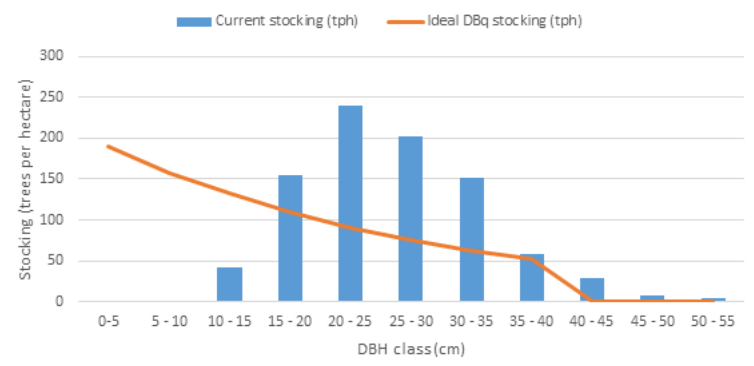

Fig. 2: Actual pre-treatment stocking and ideal DBq stocking of Chapani forest (DBq stocking derived for $q-$ factor $=1.2$, target basal area $=\mathbf{3 0}$ $\mathrm{m}^{2}, \mathrm{DBH}$ limit $=40 \mathrm{~cm}$ )

Example of application of $\mathrm{DBq}$ regime for Lampata Sal Forest (Taksar, Lamjung)

Lampata community forest (CF) has a total land area of 75 hectares. It consists of Shorea robusta (Sal) with some Castanopsis indica (Katus) and Schima wallichii (Chilaune) managed by 246 households, of which the effective forest area is estimated to be 55 ha. Like other community forests in Nepal, Lampata CF is managed for timber, fuel wood, grass and leaf litter. Due to high number of forest users, slow growth of timber and full stocking of forest, the forest users often encounter shortage of fuel wood and fodder from the forest. Timber is generally provided to user on a priority basis at a forest user's timber price that is $25 \%$ of the market price for Sal. Sale of Sal timber to outside the village has not been experienced by the forest users due to conservative annual allowable cut.

The Lampata forest is a natural regeneration that developed by a strict prohibition of open grazing in the forest and currently it has an uneven age structure showing and inverse J-shape DBH distribution (Fig. 3). As argued earlier, this stocking distribution was achieved by ad hoc negative tree selection; the forest user group is challenged by the lack of trees that may be available to meet forest users' needs for timber. It is also observed that the quality of seedlings and saplings is very low although there is sufficient number on the forest floor. The quality of standing trees is also poor due to lack of information on assessing tree quality. The ideal $\mathrm{DBq}$ stocking shown in figure 3 suggests that trees over $40 \mathrm{~cm}$

Table 2: Current stocking, ideal stocking, marking guide, residual stocking and harvest volume before and after $\mathrm{DBq}$ single tree selection treatment in Chapani forest

\begin{tabular}{|c|c|c|c|c|c|c|c|c|}
\hline $\begin{array}{c}\text { DBH class } \\
\text { (cm) }\end{array}$ & $\begin{array}{l}\text { Plot } \\
\text { tree } \\
\text { count* }\end{array}$ & $\begin{array}{c}\text { Current } \\
\text { stocking } \\
\text { (tph) }\end{array}$ & $\begin{array}{c}\text { Ideal DBq } \\
\text { stocking } \\
\text { (tph)** }\end{array}$ & $\begin{array}{l}\text { Marking } \\
\text { guide*** }\end{array}$ & $\begin{array}{c}\text { Plot } \\
\text { residual } \\
\text { tree } \\
\text { count }\end{array}$ & $\begin{array}{c}\text { Residual } \\
\text { stocking } \\
\text { (tph) }\end{array}$ & $\begin{array}{c}\text { Plot har- } \\
\text { vested tree } \\
\text { volume } \\
(\mathrm{m} 3) * * * *\end{array}$ & $\begin{array}{c}\text { Plot re- } \\
\text { sidual tree } \\
\text { volume } \\
(\mathrm{m} 3)^{* * * *}\end{array}$ \\
\hline $0-5$ & $-a$ & $-\mathrm{a}$ & 190 & 4 & - & - & - & - \\
\hline $5-10$ & 0 & 0 & 158 & 3 & - & - & $-b$ & $-b$ \\
\hline $10-15$ & 10 & 24 & 132 & 3 & 1 & 2 & 0.86 & 0.06 \\
\hline $15-20$ & 37 & 88 & 110 & 2 & 7 & 17 & 4.83 & 1.15 \\
\hline $20-25$ & 57 & 136 & 91 & 2 & 19 & 45 & 12.92 & 6.12 \\
\hline $25-30$ & 48 & 114 & 76 & 2 & 20 & 48 & 15.91 & 10.74 \\
\hline $30-35$ & 36 & 86 & 63 & 1 & 16 & 38 & 16.15 & 12.72 \\
\hline $35-40$ & 14 & 33 & 53 & 1 & 9 & 21 & 5.68 & 11.17 \\
\hline $40-45$ & 7 & 17 & - & - & 5 & 12 & 3.11 & 8.02 \\
\hline $45-50$ & 2 & 5 & - & - & 1 & 2 & 2.19 & 1.95 \\
\hline $50-55$ & 1 & 2 & - & - & & 0 & 1.37 & - \\
\hline Total & 212 & 505 & 873 & 18 & 78 & 185 & 63.0 & 51.9 \\
\hline \multicolumn{9}{|c|}{$\begin{array}{l}* \text { Plot area is } 4200 \mathrm{~m}^{2} \\
* * \text { Ideal stocking }=q \text { factor } 1.2, \text { DBH limit }=40 \mathrm{~cm} \text {, basal area } 30 \mathrm{~m}^{2} \\
\text { ***Marking guide = number of trees per } 10 \mathrm{~m} \times 20 \mathrm{~m} \text {, the number of trees was derived by dividing the ideal stocking for each DBH class by } \\
50 \text { and rounded to the next higher number of trees. } \\
* * * * \text { Standing tree volume was calculated following Cedamon et al. } \\
\text { aSeedlings were not counted during the pre-treatment inventory but generally seedlings were not present. } \\
\text { b Tree volume for this DBH class was not calculated. }\end{array}$} \\
\hline
\end{tabular}


DBH may be available for harvest representing $6 \%$ of the total tree count. As shown in figure 3 , stocking in DBH classes in $15-40 \mathrm{~cm}$ are all below or on the ideal $\mathrm{DBq}$ line indicating that all trees in these classes should be retained but is not the case due to the need to cut bad and deformed trees in the stand to make sure that regeneration is coming from healthy and vigorous mother trees.

The abundance of poor quality poles and saplings make the single tree selection regime challenging for Lampata forest. As shown in table 3, more than half of the saplings and poles were removed representing $39-45 \%$ of the total timber stock. The FUG also decided to remove deformed and damaged large trees to allow better and faster growth of good quality trees on the same size class and in lower size class removing just over half of the standing volume of sawlogs. The selection system implemented in Lampata may be seen as over harvesting but in reality the regime is able to refine the stand by removing badly damaged large size Chilaune and Sal trees as well as poles and saplings. The treated stand is currently showing abundant healthy regeneration and a faster and better growth of residual saplings and poles. The forest is proud of this system in that it has retained healthy and vigorous residual trees with a better stand structure compared to irregular shelterwood system applied in a nearby forest. A plot demonstrating conversion of current forest to timber-fodder forest garden was established on Lampata forest using guided by the ideal stocking for q-factor of 1.2.

The major challenge in implementing DBq-based single tree selection regime in forests like the Lampata forest is the difficulty in achieving the ideal stocking on a per hectare basis. This is due to the fact that most forests have irregular spacing of trees such that some patches are dense and others are sparse. Following the marking guide for a 10 $\mathrm{m} \times 20 \mathrm{~m}$ plot (Tables 2 and 3 ) it is possible that the residual stocking may be lower than the ideal stocking. However this can be easily corrected in the succeeding cutting operations.

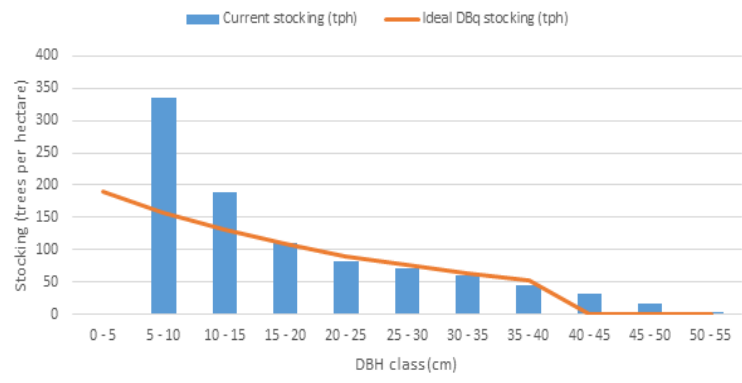

Fig. 3: Actual pre-treatment stocking and ideal DBq stocking of Lampata forest (DBq stocking derived for $q$-factor $=1.2$, target basal area $=\mathbf{3 0}$ $\mathrm{m}^{2}, \mathrm{DBH}$ limit $=40 \mathrm{~cm}$ )

Table 3: Current stocking, ideal stocking, marking guide, residual stocking and harvest volume before and after DBq single tree selection treatment in Lampata forest

\begin{tabular}{lcccccccc}
\hline $\begin{array}{c}\text { DBH class } \\
(\mathbf{c m})\end{array}$ & $\begin{array}{c}\text { Plot } \\
\text { tree } \\
\text { count* }\end{array}$ & $\begin{array}{c}\text { Current } \\
\text { stocking } \\
\text { (tph) }\end{array}$ & $\begin{array}{c}\text { Ideal DBq } \\
\text { stocking } \\
(\mathbf{t p h}) * *\end{array}$ & $\begin{array}{c}\text { Marking } \\
\text { guide*** }\end{array}$ & $\begin{array}{c}\text { Plot } \\
\text { residual } \\
\text { tree } \\
\text { count }\end{array}$ & $\begin{array}{c}\text { Residual } \\
\text { stocking } \\
(\mathbf{t p h})\end{array}$ & $\begin{array}{c}\text { Plot har- } \\
\text { vested tree } \\
\text { volume } \\
(\mathbf{m} 3)^{* * * *}\end{array}$ & $\begin{array}{c}\text { Plot re- } \\
\text { sidual tree } \\
\text { volume } \\
(\mathbf{m 3} \mathbf{3}) * * *\end{array}$ \\
\hline $0-5$ & $-\mathrm{a}$ & $-\mathrm{a}$ & 190 & 4 & - & - & - & - \\
$5-10$ & 134 & 335 & 158 & 3 & 2 & 5 & $-\mathrm{b}$ & $-\mathrm{b}$ \\
$10-15$ & 76 & 190 & 132 & 3 & 31 & 78 & 1.95 & 2.42 \\
$15-20$ & 44 & 110 & 110 & 2 & 27 & 68 & 3.20 & 4.95 \\
$20-25$ & 33 & 83 & 91 & 2 & 20 & 50 & 3.84 & 9.08 \\
$25-30$ & 29 & 73 & 76 & 2 & 15 & 38 & 9.52 & 10.43 \\
$30-35$ & 24 & 60 & 63 & 1 & 10 & 25 & 15.42 & 12.49 \\
$35-40$ & 18 & 45 & 53 & 1 & 8 & 20 & 15.19 & 14.62 \\
$40-45$ & 13 & 33 & - & - & 5 & 13 & 14.98 & 11.17 \\
$45-50$ & 7 & 18 & - & - & 3 & 8 & 10.42 & 8.51 \\
$50-55$ & 2 & 5 & - & - & - & - & 6.22 & - \\
\hline Total & $\mathbf{3 8 0}$ & $\mathbf{9 5 2}$ & $\mathbf{8 7 3}$ & $\mathbf{1 8}$ & $\mathbf{1 2 1}$ & $\mathbf{3 0 5}$ & $\mathbf{8 0 . 7 4}$ & $\mathbf{7 3 . 6 7}$ \\
\hline
\end{tabular}

Information on these symbols and letters, *, **, ***,****, a, b are given in table 2. 
Proposed guidelines for selection silviculture system in Nepal

Moving on from demonstration plot to whole forest silviculture intervention, the following steps are proposed as a simple guideline for implementing single tree selection silviculture system on community forests in Nepal.

Step 1: Decide on the desired basal area $\left(\mathrm{m}^{2}\right)$ of residual stand and largest target diameter class.

Step 2: Decide on a q- factor (between 1.1-2.0).

Step 3: From table of K values derived by Cancino and Gadow (2002) provided in table 1, find the $\mathrm{K}$ values for desired $\mathrm{q}$-factor and max, say $\mathrm{q}=1.3$, largest $\mathrm{DBH}=40 \mathrm{~cm}=0.684$.

Step 4: Using $\mathrm{K}$ values, calculate the number of trees (Ni) for the largest diameter class for one hectare stand. For example, if the desired basal area of $30 \mathrm{~m}^{2}$, then $\mathrm{Ni}=30 / 0.684=43.8596 \approx 44$ trees.

Step 5: Once the number of trees in the largest diameter class is obtained, calculate for the next lower diameter class, $\mathrm{Ni}-1=44 * 1.3=57.2 \ldots$ and so on. (Calculations for q-factor 1.2-1.6 for basal area $30 \mathrm{~m}^{2}$ and $40 \mathrm{~m}^{2}$ is provided in appendix 1)

Step 6: From the data of forest inventory either following the Community Forest Inventory Guideline or based on Rapid Silviculture Appraisal (Cedamon et al., 2016), derive the actual tree distribution by DBH classes. Then, calculate the number of harvestable stems per DBH class $=$ actual stocking - ideal stocking

Step 7: Calculate the harvestable volume per ha $(\mathrm{HVH})=$ average stem volume on the dbh class * number of harvestable stem per DBH class (step 6)

Step 8. Calculate the harvestable volume for the whole forest $(\mathrm{WFV})=\mathrm{HVH} *$ area of the forest $=$ example $200 \mathrm{cu} . \mathrm{m} . / \mathrm{ha} * 120 \mathrm{ha}=200 * 120=24,000$ cu.m.

Step 8: Calculate the felling cycle $=$ WFV $/ A A C$, for example $\mathrm{AAC}=600,24000 / 600=40$ years

Step 9: Determine the Annual Felling Area = Forest Area/ Felling Cycle Length (years) $=120$ ha/ $/ 40$ years $=3$ ha/year
Step 10: For each felling area, derive the ideal residual stocking per hectare and the number of trees per DBH class for $10 \mathrm{~m}$ x $20 \mathrm{~m}$ sub-plot for marking residual trees. See examples from Lampata and Chapani forests for this procedure. Follow existing guidelines for marking trees and documentation required for obtaining harvesting permit.

\section{Conclusion}

Many community forests in Nepal are managed based on ad hoc 'selection system', removal of dead and dying as well as few big trees. There is now an increasing interest to manage community forests based on scientific forestry, however, examples of practicing scientific forest management and practical guidelines are lacking. This paper tried to present selection silviculture system based on diameter distribution, basal area and q-factor (DBq). As shown in the examples for Chapani and Lampata forests, DBq selection silviculture system is not necessarily difficult if target DBH distribution for residual stocking is provided to forest user groups in guiding harvesting. The authors believed that misunderstanding of how 'proper' selection silviculture works has caused much reluctance by foresters to accept or to apply it. The misunderstanding is exacerbated with confusion between late thinning and selection silviculture system which boundaries between the two are often not understood. Another issue with regard to selection silviculture system is the difficulty to harvest marked trees over a range of diameter classes without damaging the residual growing stock. To some degree this is true but this is other silviculture system except clear felling may also pose damage to residual trees. Given that tree felling and skidding on community forests in Nepal is generally manual, tree damage will always occur and that tree damage is generally low.

Selection silviculture system based on $\mathrm{DBq}$ is generally new in community forestry, trainings should be provided to foresters who could then provide trainings to forest users. Silviculture demonstration plots established by EnLiFT are generally important show cases to assist these trainings. In delivering trainings, it is important that foresters are refreshed with theories and principles of forest ecology and management to be able to fully grasp uneven age forest management 
and implementation of silviculture system based on diameter distribution.

The examples from Chapani and Lampata forests provided in this paper are simple guidelines for practicing selection silviculture based on reverse $\mathrm{J}$ curve. In deriving the residual stocking for $\mathrm{DBq}$ selection, the $\mathrm{K}$ value is the key parameter for calculating the number of residual trees. These values are provided in table 1 to allow foresters to calculate stocking not provided in appendix 1 . The implementation of DBq system is assisted with a tree marking guide which provides the number of residual trees in a particular DBH class for $10 \mathrm{~m}$ x $20 \mathrm{~m}$ sub-plot. The size of the marking plot may be decreased or increased depending on the pre-treatment tree density

\section{References}

Awasthi, N., Bhandari, S. K. and Khanal, Y. 2015. Does scientific forest management promotes plant species diversity and regeneration in Sal (Shorea robusta): a case study from Lumbini collaborative forest Rupandehi Nepal. Banko Janakari 25 (1): 20-29.

Cancino, J. and von Gadow, K. 2002. Stem number guide curves for uneven-aged forest, developments and limitations, In Continuous Cover Forestry: Managing Forest Ecosystems Volume 4 (eds.) von Gadow, K., Pukkala, T. and Tome, M., Springer, Dordrecht, 163174.

Cedamon, E., Nuberg, I., Paudel, G., Basyal, M., Shrestha, K. and Paudel, N. 2016. Rapid silviculture appraisal to characterise stand and determine silviculture priorities of community forests in Nepal. Small-scale Forestry 16 (2): 195-218. DOI 10.1007/ s11842-016-9351-0.
DoF. 2015. Community Forestry Users Group Database record available in MIS, Department of Forests (DoF). Report Date: 25 August 2015, http://dof.gov.np/image/ data/Community_Forestry/Summary.pdf, accessed 9/09/2015.

DoF. 2015. The Scientific Forest Management Guideline 2015. Department of Forests, Kathmandu, Nepal.

DFRS. 2015. State of Nepal's Forests. Forest Resource Assessment (FRA) Nepal, Department of Forest Research and Survey (DFRS). Kathmandu, Nepal.

Helms, J. (ed.). 1998. The Dictionary of Forestry. Society of American Foresters, Bethesda, MD, USA.

Larsen, J. 1995. Ecological stability of forests and sustainable silviculture. Forest Ecology and Management 73 (1-3): 85-96

Nepal Australia Community Resource Management and Livelihoods Project. 2006. Rough Guide to the Potential Value of the Plantations. Project Coordination Committee Meeting, 30 May 2006, unpublished power point slides.

O'Hara, K. 2014. Multi-aged Silviculture: Managing for Complex Forest Stand Structures. Oxford University Press, Oxford, UK.

O'Hara, K. and Gersonde, R. 2004. Stocking control concepts in uneven-aged silviculture. Forestry 77 (2): 131-143.

Smith, D., Larson, B., Kelty, M. and Ashton, P. M. 1997. The Practice of Silviculture: Applied Forest Ecology. 9th Edition, John Wiley \& Sons, New York, USA. 